\title{
TALES OF IMPOSSIBILITY
}





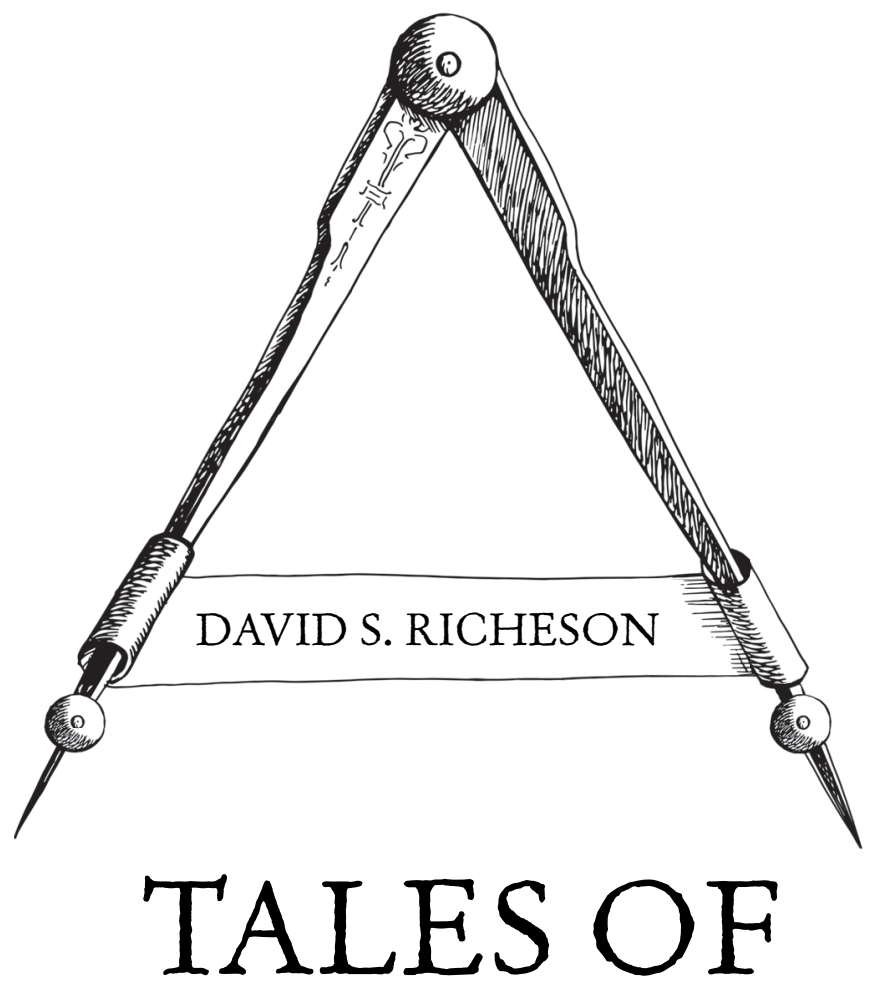

\title{
IMPOSSIBILITY
}

\author{
The 2000-Year Quest \\ to Solve the Mathematical \\ Problems of Antiquity
}

Princeton University Press

Princeton and Oxford 
Copyright (C) 2019 by Princeton University Press

Published by Princeton University Press

41 William Street, Princeton, New Jersey 08540

6 Oxford Street, Woodstock, Oxfordshire OX20 1TR

Requests for permission to reproduce material from this work should be sent to permissions@press.princeton.edu

press.princeton.edu

All Rights Reserved

Library of Congress Control Number: 2019941488

ISBN 978-0-691-19296-3

British Library Cataloging-in-Publication Data is available

Editorial: Vickie Kearn, Susannah Shoemaker, and Lauren Bucca

Production Editorial: Karen Carter

Text and Jacket/Cover Design: C. Alvarez-Gaffin

Production: Jacquie Poirier

Publicity: Katie Lewis and Sara Henning-Stout

Copyeditor: Alison Durham

Jacket art courtesy of Shutterstock

This book has been composed in Palatino

Printed on acid-free paper. $\infty$

Printed in the United States of America

$\begin{array}{llllllllll}10 & 9 & 8 & 7 & 6 & 5 & 4 & 3 & 2 & 1\end{array}$ 
Whenever things sound easy, ... it turns out there's one part you didn't hear.

-Donald Westlake ${ }^{1}$ 
